\title{
Evaluation of Adaptability of Mung Bean Varieties in Moisture Stress of Eastern Harerghe Zone
}

\author{
Habte Umata* \\ Fadis Agricultural Research Center, Ethiopia
}

Submission: September 15, 2017; Published: January 09, 2018

"Corresponding author: Habte Umata, Fadis Agricultural Research Center, Ethiopia, Tel: 919900073; Email: habtiyebirish@gmail.com

\begin{abstract}
The experiment was conducted for two years (2015 \& 2016) at two locations (Fadis and Erer) with objective of evaluate and promote improved mung bean varieties for their wider adaptability and agronomic performance. The analysis of variance revealed that there was significant $(\mathrm{p}<0.05)$ difference among the varieties for their grain yield at Fadis and Erer. Rasa and Borada earned high grain yield percentage than that of the Arbeke and Standard check (shewarobit). Therefore, Rasa and (Borada) improved mung bean varieties were recommended for further demonstration to the respective area of Fadis, Erer and similar agro-ecologies. Key word: variety, mung bean and adaptability.
\end{abstract}

\section{Introduction}

Mungbean is one of the most important pulse crops, grown from the tropical to sub-tropical areas around the world [1,2]. It is an important wide spreading, herbaceous and annual legume pulse crop cultivated mostly by traditional famers [3]. The crop is characterized by fast growth under warm conditions, low water requirement and excellent soil fertility enhancement via nitrogen fixation Yagoob \& Yagoob [4]. Fertilization of this crop occurs through self-pollination without requirement of other pollinators like insects, water and wind [5]. Among legumes, mung bean is noted for its protein and lysine-rich grain, which supplements cereal-based diets [2,6]. The crop is utilized in several ways; seeds, sprouts and young pods are all consumed and provide a rich source of amino acids, vitamins and minerals [7]. The grain contains $24.2 \%$ protein, $1.3 \%$ fat and $60.4 \%$ carbohydrate [8]. It is also known to be very healthy and packed with a variety of nutrients such as vitamin B, vitamin C, protein, manganese and a lot of other essential nutrients required for effective functioning of the human health. Mungbean has low in calories and rich in fiber and easily digestible crop without cause flatulence as happens with many other legumes [6].

\section{Climatic requirements of mung bean}

Mung bean is a warm season crop requiring 90-120 days of frost-free conditions from planting to maturity (depending on the variety). The optimum temperature range for growth is between $27{ }^{\circ} \mathrm{C}$ and $30{ }^{\circ} \mathrm{C}$. This means that the crop is usually grown during summer. Seed can be planted when the minimum temperature is above $15{ }^{\circ} \mathrm{C}$. Mung beans are responsive to daylight length. Short days result in early flowering, while long days result in late flowering. However, mung bean varieties differ in their photoperiod response. Mung bean is considered to be heat and drought tolerant. Mung beans are propagated from seed. A seeding rate that will ensure a plant population of 200 000 to 350000 plants/ha under dry-land conditions and 400 000 plants/ha under irrigation, is recommended.

According to ECXA [9], mung bean is being cultivated as a recently introduced crop in Ethiopia. As Asfaw et al. 2012 reported, in Ethiopia mung bean is mostly grown by smallholder farmers under drier marginal environmental condition and the production capacity is lower than other pulse crops. For resource poor farmers in Ethiopia, mung bean is mainly used as food, but growing it for income generation can also be important.

\section{Importance of mung bean}

Among pulses, mung bean is the most important cash crops in the world $[7,10]$. It is a vital crop in developing countries where it is consumed as dry seeds, fresh green pods or leaves due to its high protein, vitamin and mineral content. It is also consumed as forage or green pods and seeds as vegetables $[11,12]$. Primarily, the purposes of this crop are for its protein rich edible seeds and fresh sprout. The seed of mung bean mainly used for making soups, bread and biscuits [13]. Other than food it 
is importance to assistance in normal use of land, water resource and enrichment of the soil through nitrogen fixation. Adaptation to short growth duration, low water requirement, ability to increase soil fertility and usefulness in crop rotation practices are also another significances of mung bean [12]. And also it has the Ability of improving soil fertility by fixing atmospheric nitrogen into available form with the help of rhizobia species for plant's growth and development are characters of mung bean $[14,15]$.

Mung beans do best on fertile, sandy loam soils with good internal drainage and a $\mathrm{pH}$ in the range of 6.3 and 7.2. Mung beans require slightly acid soil for best growth. If they are grown in rotation, lime to attain $\mathrm{pH}$ of the most acid sensitive crop. Root growth can be restricted on heavy clays. Mung beans do not tolerate saline soils and can show severe iron chlorosis symptoms and certain micronutrient deficiencies on more alkaline soils. It is known that East Harerghe is predominated by cereal crops (particularly sorghum and rarely maize) production and chat. This monoculture makes the soil degradation and erosion. Rotation of cereals with legume crops is not practiced. Although now days some legumes are rarely grown on small scale around low (haricot bean, soybean,) and highlands (faba bean, field pea, lentil) of East Harerghe zone. Even though there are some pulse crops grown in the areas still the felt need of the community is not meet. The community has introduced this crop through ZOAP ROJEECT around Midhaga Tola in 2014 and their desire to this crop is highly increasing though the net yield per hectare is of the under production is low, due to its multiple uses locally and high demand in the market .

The mung bean variety which came through ZOA PROJECT has not assessed under the existing condition before distributed to the community and unknown sources and inferior in agronomic quality and low yield. Also it is single in number. No alternatives to use this type of varieties. Therefore, it was becoming very important to collect different improved varieties to evaluate for their wider adaptability to lowlands of East Harerghe areas.

\section{Materials and Methods}

\section{Description of experimental site}

The study was conducted under rain fed conditions at two location (Fadis; Boko site) and Erer sub-site. Fadis, is located at the latitude of $9^{\circ} 07^{\prime}$ north and longitude of $42^{\circ} 04^{\prime}$ east, inthe middle and lowland areas and at the altitude of 1702 meters above sea level, with a prevalence of lowlands. The area is situated at the distance of about $24 \mathrm{~km}$ from Harar town in the southerly direction. The experimental area is characterized a slow land climate. The mean rainfall is about $860.4 \mathrm{~mm}$ for the last five years. The rainfall has a bimodal distribution pattern with heavy rains from April to June and long and erratic rains from August to October. The mean maximum and minimum annual temperature are $28.2{ }^{\circ} \mathrm{C}$ and $10.2{ }^{\circ} \mathrm{C}$, respectively, for the last five years (Fadis Agriculture Research Center Metrological Station). Similarly the second study area, Erer valley of Babile Woredas, is located at $34 \mathrm{~km}$ from Harar city in eastern direction in eastern part of Ethiopia in Oromia Regional State at lowland of Harerghe Zone. The area receives an average annual rainfall of about $400-600 \mathrm{~mm}$. The altitude of the area lay between 950 2000 meters at sea level.

\section{Experimental materials}

Four mung bean varieties were used as the experiment materials. These planting materials were collected from different Agricultural research center. Two varieties (Borada and Rasa) were collected from Melkasa Agricultural Research Center, one variety (Arbeke) from Tigrai Regional state and one variety (Shewarobit) from ZOA project. The study was conducted under rain fed for two consecutive years during 2015 and 2016. The experimental plots were laid out in Randomized Complete Block Design (RCBD) with three replications. All quantitative data (Flowering date, Maturity date, Pod per plant, Seed per pod and Grain yield (kg/ha) were collected. Data were analyzed using GenSTAT statistical software package and mean values or Least Significant Differences (LSD) were compared using the procedures of Duncan's at the $5 \%$ level of significance.

\section{Results and Discussion}

Table 1: Combined mean of grain yield, pod/plant and seed/pod of mung bean across location (Fadis and Erer) of 2015

\begin{tabular}{|c|c|c|c|c|c|}
\hline Treatment Name & Flowering Date & Maturity Date & Pod Per Plant & Seed Per Pod & Grain Yield(Kg/Ha) \\
\hline Arbeke & $40.33 a$ & 73.5 & $8.33 c$ & 8.833ab & $493.3 b$ \\
\hline Borada & $38.83 \mathrm{ab}$ & 73.33 & $10.83 b$ & $9.5 \mathrm{ab}$ & $786.8 \mathrm{a}$ \\
\hline Rasa & $37.33 \mathrm{~b}$ & 72.83 & $14.5 \mathrm{a}$ & $10.333 a$ & $662.1 \mathrm{ab}$ \\
\hline St check & $41.33 a$ & 74.67 & $11.67 \mathrm{~b}$ & $8.167 \mathrm{~b}$ & $495.7 \mathrm{~b}$ \\
\hline l.s.d & 2.882 & NS & 2.328 & 1.787 & 206.2 \\
\hline $\mathrm{Cv}$ & 4.2 & 11.9 & 11.7 & 11.1 & 19.3 \\
\hline
\end{tabular}

NB: L.s.d: Least Significant Difference; Cv: Coefficient Variation; St: Standard; NS: Not Significant

The results of the first year (2015) showed that there was no significant difference on maturity date at two locations (Fadis and Erer). But significant difference was observed on:
Flowering date, Seed per pod, Pod per plant and grain yield. Maximum grain yield $786.8 \mathrm{~kg} / \mathrm{ha}$ was harvested from Borada followed by Rasa $(662.1 \mathrm{~kg} / \mathrm{ha})$. Maximum number of pod per 
plant 14.5 and number of seed per pod 10.3 were observed on Rasa. Minimum numbers of pods per plant 8.3 on Arbeke and minimum numbers of seeds per pod 8.2 on St Check. The result shows that flowering date, maturity date, pod per plant and seed per pod has no significant difference over locations (Fadis and Erer) in 2016 were as grain yield show significance difference at $\mathrm{p}<5 \%$. The maximum grain yield were collected from Rasa (644.5kg/ha) and Borada (644.4 kg/ha). The minimum grain yield was harvested from Arbeke $(419.8 \mathrm{~kg} / \mathrm{ha})$. The analysis of variance revealed that there was significant $(p<0.05)$ difference among the varieties for their grain yield at Fadis and Erer. Rasa and Borada earned high grain yield percentage than that of the
Arbeke and Standard check (shewarobit) (Table 1).

From analysis of ANOVA the overall mean interaction of location and years; flowering date pod per plant, seed per pod and grain yield shows significant differences (5\%). From our observation the Arbeke and standard check varieties were highly infected with Cercospora leaf spot disease. Similar study conducted by Chadha [16] reported that all parts of crop plant including root, stem, branches, petiole, leaves, pods and seeds of the crops are vulnerable to disease and pest. Ashrar [17] considered the low yield potential of mungbean is due to susceptibility to insect pests, and diseases [18] (Table $2 \& 3$ ).

Table 2: The combined mean of yield and yield related parameter of mung bean at Fadis and Erer for 2016 production year

\begin{tabular}{|c|c|c|c|c|c|}
\hline Treatment Name & Flowering Date & Maturity Date & Pod Per Plant & Seed Per Pod & Grain Yield(Kg/Ha) \\
\hline Arbeke & 42.33 & 70.5 & 11.1 & 9.167 & $419.8 b$ \\
\hline Borada & 40.67 & 74 & 12.67 & 10 & $644.4 \mathrm{a}$ \\
\hline Rasa & 38.67 & 69.67 & 15.1 & 8.333 & $644.5 \mathrm{a}$ \\
\hline St check & 42 & 72.67 & 12.57 & 9.833 & $470.7 \mathrm{~b}$ \\
\hline l.s.d & 4.184 & 5.686 & 4.287 & 2.027 & 109.7 \\
\hline $\mathrm{Cv}$ & 5.8 & 4.5 & 19 & 12.4 & 11.5 \\
\hline
\end{tabular}

NB: L.s.d: Least Significant Difference; Cv: Coefficient Variation; St: Standard; NS: Not Significant

Table 3: overall location and year interaction of flowering date, maturity date, pod per plant, seed per pod and grain yield (kg/ha).

\begin{tabular}{|c|c|c|c|c|c|}
\hline Treatment Name & Flowering Date & Maturity Date & Pod Per Plant & Seed Per Pod & Grain Yield(Kg/Ha) \\
\hline Arbeke & $41.33 a$ & 72 & $9.8 \mathrm{~b}$ & $9 a b$ & $456.5 b$ \\
\hline Borada & $39.75 a b$ & 73.67 & $12.82 \mathrm{a}$ & $10.083 a$ & $715.6 a$ \\
\hline Rasa & $38 b$ & 71.25 & $11.75 \mathrm{ab}$ & $9.75 \mathrm{ab}$ & $653.3 a$ \\
\hline St check & $41.67 a$ & 73.67 & $9.72 b$ & $8.25 b$ & $483.2 \mathrm{~b}$ \\
\hline L.s.d. & 2.421 & NS & 2.44 & 1.102 & 80.5 \\
\hline $\mathrm{Cv} \%$ & 7.3 & 6 & 24.5 & 14.4 & 16.9 \\
\hline
\end{tabular}

NB: L.s.d: Least Significant Difference; Cv: Coefficient Variation; St: Standard; NS: Not Significant

From this graph the varieties Arbeke and shewarobit were highly susceptible to Cercospora leaf spot disease where as
Borada and Rasa varieties have resistant reaction against the diseases (Figure 1).

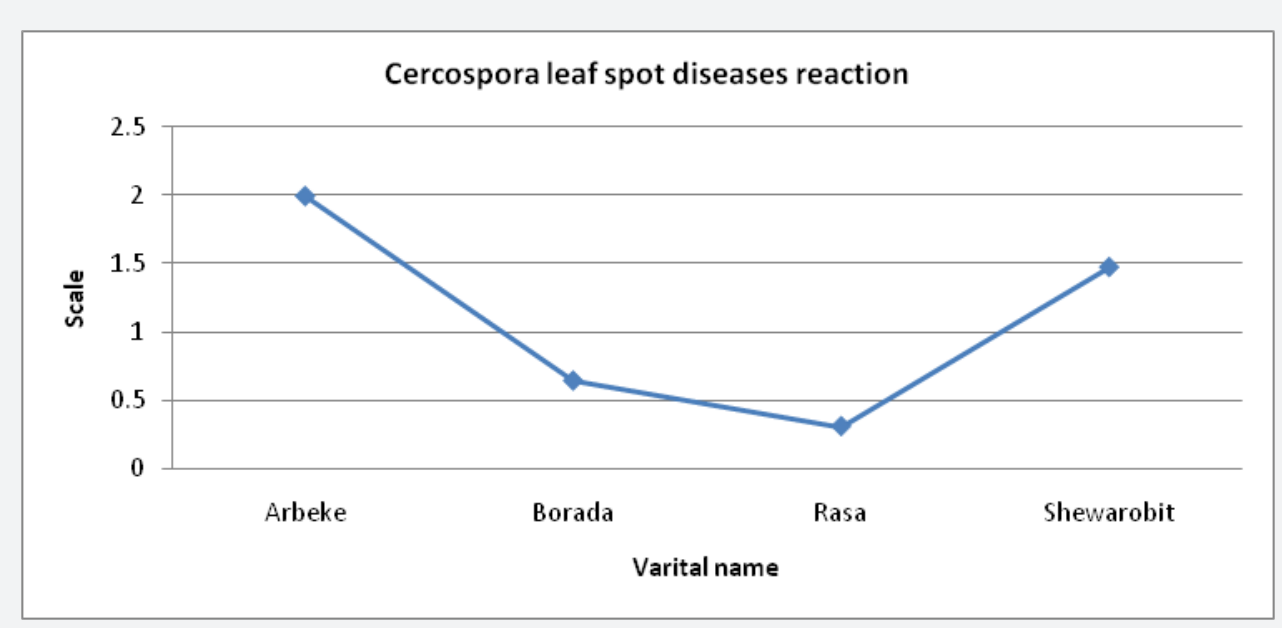

Figure 1: Cercosporal leaf spot diseases reaction. 
Except maturity date all the parameters; flowering date, pod per plant, seed per pod and grain yield were showing significant differences among the tested varieties at both locations and years.

Therefore, Rasa and Borada improved mung bean varieties were recommended for further production to the respective area of Fadis, Erer and similar agro-ecologies.

\section{References}

1. Kumari R, Shekhawat KS, Gupta R, Khokhar MK (2012) Integrated management against root- rot of mungbean (Vignaradiata L.) Wilczek) incited by macrophominaphaseolina. J Plant Pathol Microb 3: 5.

2. Khan MA, Naveed K, Ali K, Ahmad B, Jan S (2012) Impact of mungbeanmaize intercropping on growth and yield of mungbean. Weed science society of Pakistan department of weed science. J Weed Sci Res 18(2): 191-200.

3. Ali MZ, Khan MAA, Rahaman AKMM, Ahmed M, Ahsan AFMS (2010) Study on seed quality and performance of some mungbean varieties in Bangladesh. Int J Expt Agric 1(2): 10-15.

4. Yagoob H, Yagoob M (2014) The effects of water deficit stress on protein yield of mungbean genotypes. Peak Journal of Agricultural Science 2(3): 30-35.

5. Rashid K, Daran ABM, Nezhadahmadi A, Yusof MFBM, Azhar S, et al. (2013) Intraspecific crosses and morphological studies of two cultivars of Vigna radiate through in-vitro and in-vivo techniques. Life Science Journal 10 (2): 2549-2555.

6. Minh NP (2014) Different factors affecting to mungbean (Phaseolus aureus) tofu production. International Journal of Multidisciplinary Research and Development 1(4):105-110.

7. Somta P, Srinives $P$ (2007) Genome research in mung bean (Vignaradiata L.) Wilczek) and black gram (V mungo L.) Hepper). Science Asia 33(s1): 69-74.
8. Hussain F, Malik AU, Haji MA, Malghani AL (2011) Growth and yield response of two cultivars of mungbean (Vignaradiata L.) to different potassium levels. The Journal of Animal \& Plant Sciences 21(3): 622625 .

9. ECX (2014) Ethiopia Commodity Exchange Rings Bell for mungbean Addis Ababa.

10. Pandey A, Kumar A, Ramya P (2011) Genetic diversity in green gram accessions as revealed by STMS markers. African Journal of Biotechnology 10(75):17081-17087.

11. Tang D, Dong Y, Ren H, He C (2014) A review of photochemistry metabolite changes and medicinal uses of the common food mungbean and its' sprouts (Vignaradiata). Chemistry Central Journal 8: 4.

12. Das S, Shekhar UD, Ghosh P (2014) Assessment of molecular genetic diversity in some green gram cultivars as revealed by ISSR analysis. Advances in Applied Science Research 5(2): 93-97.

13. Sehrawat N, Bhat KV, Sairam RK, Pawan KJ (2013) Identification of salt resistant wild relatives of mungbean (Vignaradiata L.) Wilczek). Asian Journal of Plant Science and Research 3(5): 41-49.

14. Singh R, Heusden AW, Yadav RC (2011) A comparative genetic diversity analysis in mungbean (Vignaradiata L.) using inter-simple sequence repeat (ISSR) and amplified fragment length polymorphism. AFLP 12(47): 6574-6582.

15. Jat SL, Prasad K, Parihar CM (2012) Effect of organic manuring on productivity and economics of summer mungbean (Vignaradiata Var. radiata). Ann Agric Res New series 33(12): 17-20.

16. Chadha ML (2010) Short duration mungbean: a new success in South Asia. Asia-Pacific association of agricultural research institutions.

17. Ashrar M, Siririnives P, Sadiq MS, Saleem M (2001) AVRDC Germplasm: Its utilization and development of improved mungbean. Pak J Bot 33.

18. Asrat A, Fekadu G, Fetsum AYR (2012) Analysis of multi-environment grain yield trials in mungbean (Vignaradiata L.) Wilczek based on GGE bipot in Southern Ethiopia. Agr Sci Tech 14(2): 389-398.

Your next submission with Juniper Publishers
will reach you the below assets
- Quality Editorial service
- Swift Peer Review
- Reprints availability
- E-prints Service
- Manuscript Podcast for convenient understanding
- Global attainment for your research
- Manuscript accessibility in different formats
( Pdf, E-pub, Full Text, Audio)
- Unceasing customer service
Track the below URL for one-step submission
https://juniperpublishers.com/online-submission.php

